\title{
Dura sac compression due to spinal epidural gas pseudocyst after lumbar decompression surgery: a case report
}

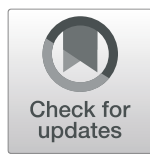

\author{
Jianwei Guo, Xuexiao Ma, Yong Liu, Guanghui Li, Dexun Wang, Zhongying Wang and Shuzhong Li*
}

\begin{abstract}
Background: Intraspinal gas pseudocyst is rare, especially following spinal surgery. Here we present a case of spinal epidural gas pseudocyst following lumbar decompression surgery, which caused dura sac compression.

Case presentation: A 52-years-old woman with chronic lumbar pain and radiating numbness of left leg was admitted to our hospital and underwent a posterior lumbar decompression surgery. 10 days later, the patient began to have dysfunction of excretion. CT and MRI were taken and epidural gas was detected, which compressed the dura sac. A huge pseudocyst encapsulated with high-tension air was found during debridement with no evidence of infection.

Results: Debridement surgery was taken to remove the encapsulated gas and cyst wall and her symptoms disappeared soon after the surgery. 2 weeks later, routine X-ray was repeated and gas pseudocyst disappeared with no signs of infection.

Conclusion: Gas pseudocyst in the spinal canal is rare, especially after lumbar surgery and causing spinal cord compression. CT and MRI can be used to detect the spinal gas. Once gas pseudocyst causes dura sac compression, proper methods should be chosen to treat this kind of intraspinal gas pseudocyst.
\end{abstract}

Keywords: Lumbar surgery, Dura sac compression, Gas pseudocyst

\section{Background}

Intraspinal gas was first reported in the intervertebral degenerative disc of the spine by Magnusson. With the use of computerized tomography (CT), intraspinal gas was becoming apparent not only in the degenerative spinal disease [1-5], but also in tumor [6,7], infection [6-8], spinal trauma [9] and iatrogenic processes [5, 10, 11]. However, it is very rare that intraspinal gas causes dura sac compression and becomes symptomatic, especially after spinal surgery. Here we present a case of gas pseudocyst following lumbar decompression surgery, which caused spinal cord compression.

\footnotetext{
* Correspondence: lishuzhong_qdfy@163.com

Department of Spine Surgery, The Affiliated Hospital of Qingdao University, 16 Jiangsu Road, Qingdao 266003, Shandong Province, People's Republic of
} China

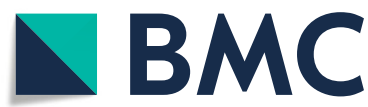

(c) The Author(s). 2019 Open Access This article is distributed under the terms of the Creative Commons Attribution 4.0 International License (http://creativecommons.org/licenses/by/4.0/) which permits unrestricted use, distribution, and reproduction in any medium, provided you give appropriate credit to the original author(s) and the source, provide a link to the Creative Commons license, and indicate if changes were made. The Creative Commons Public Domain Dedication waiver (http://creativecommons.org/publicdomain/zero/1.0/) applies to the data made available in this article, unless otherwise stated.
A 52-year-old woman was admitted to our hospital, suffering from chronic lumbar pain for ten years and aggravating after physical labour. 4 months ago, she experienced violent low back pain and numbness of left leg, radiating from left hip to the low extremity with no obvious predisposing cause. Physical examination showed tenderness of interspinal areas in the low lumbar and hypesthesia to pinprick in the L5 and S1 dermatomal distribution, as well as positive straight leg raising sign. Routine spinal X-rays showed L4 spondylolisthesis and spondylolysis in both sides. CT scan reconfirmed L4 spondylolisthesis and spondylolysis in both sides and showed evidence of disc protrusion and lumbar stenosis at $\mathrm{L} 4 / 5$ and L5/S1, compressing left L5 and S1 root (Fig. 1).

The patient subsequently took a posterior lumbar decompression surgery at L4-S1, internal fixation and intervertebral fusion at L4/5 and L5/S1. Satisfied outcome was achieved and the patient got out of our 


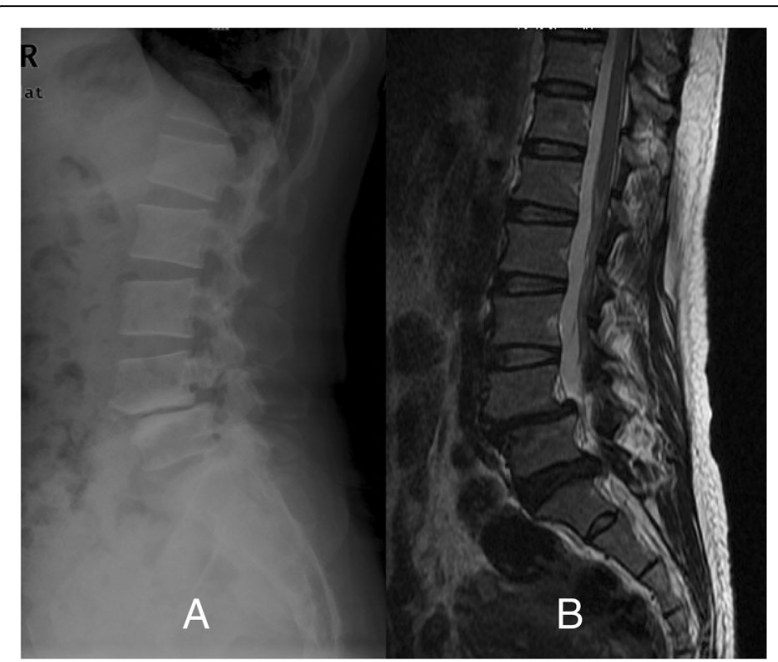

Fig. 1 Preoperative lateral X-ray (a) and sagittal MRI (b) of lumbar spine demonstrated $L 4$ spondylolisthesis and spondylolysis in both sides and disc protrusion of $L 5 / S 1$ compressing left $L 5$ and $S 1$ root

hospital at the 6th day. Routine X-ray test was taken before her discharge and showed internal fixations were in good places, but with a black shadow at the surgical place. 10 days later, the patient had an uncontrolled lumbar sprain and began to have dysfunction of excretion. She was readmitted to our hospital. CT and MRI were taken and gas pseudocyst was detected, which compressed the dura sac (Fig. 2). Laboratory studies before the revision surgery were taken to rule out the possibility of infection. Debridement surgery was taken. During the surgical procedure, a sound of rushing air was heard when the deep fascia and muscle were opened through the previous route. A thin, blister-like membranous structure surrounded with little clot organization were seen in the surgical field, significant compressing the dural sac with no sign of infection. The membranous structure and clot organization were removed until dura sac were decompressed and returned to throb. Isotonic saline and diluted iodophor solution were used to irrigate surgical field and intradiscal space at the last stage of the operation to prevent persistence of air and infection in spinal canal. Her symptoms disappeared soon after the surgery. Routine X-rays were repeated 2 weeks after debridement, and gas gap disappeared with no signs of infection (Fig. 3).

\section{Discussion}

The presence of spinal gas within an intervertebral disc or spinal canal can be seen at vertebral spondylosis [4, $12,13]$, vertebral osteomyelitis $[7,14]$, vertebral metastasis [6, 7], vertebral trauma [9], after iatrogenic manipulation [5, 10], after thoracotomy $[11,15,16]$, or Kummel disease. Spinal gas was first found in the intervertebral soft tissue of spine by Magnusson in 1937, called vacuum disc phenomenon. This so-called vacuum disc phenomenon is believed to be associated with degenerative disc disease. With the degeneration of intervertebral disc, fissuring of the fibrocartilage occurs in the desiccated nucleus pulposus and collects gas dissolved in the extracellular fluid under subatmospheric pressure [17]. This kind of gas contains more than $90 \%$ of nitrogen, which cannot be reabsorbed or replaced by liquid because of no vascular in the degenerative disc [17].

Gas collection in the spinal canal is believed to have the similar mechanism with gas collection in the degenerative disc. Gas may be originated from the venous circulation and subsequent diffuse into the vertebral canal $[15,16]$. Gas in the spinal canal, in the nerve root foramina [18], in the epidural space [13, 19], in the subarachnoid space $[20,21]$ or in a spinal epidural cyst $[22,23]$

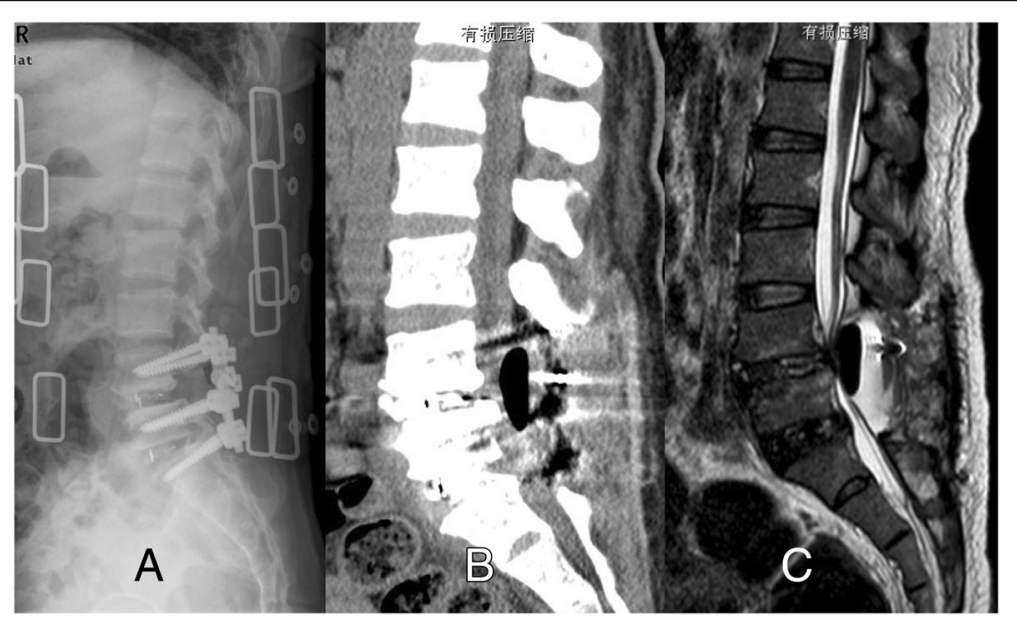

Fig. 2 Postoperative lateral X-ray of lumbar spine after surgery revealed a black shadow in the upper surgical region (a). The patient had no comfort and no intervention was taken. 10 days later, she began to have dysfunction of excretion. CT and MRI (b and $\mathbf{c}$ ) revealed a collection of epidural gas pseudocyst, compressing the spinal cord 


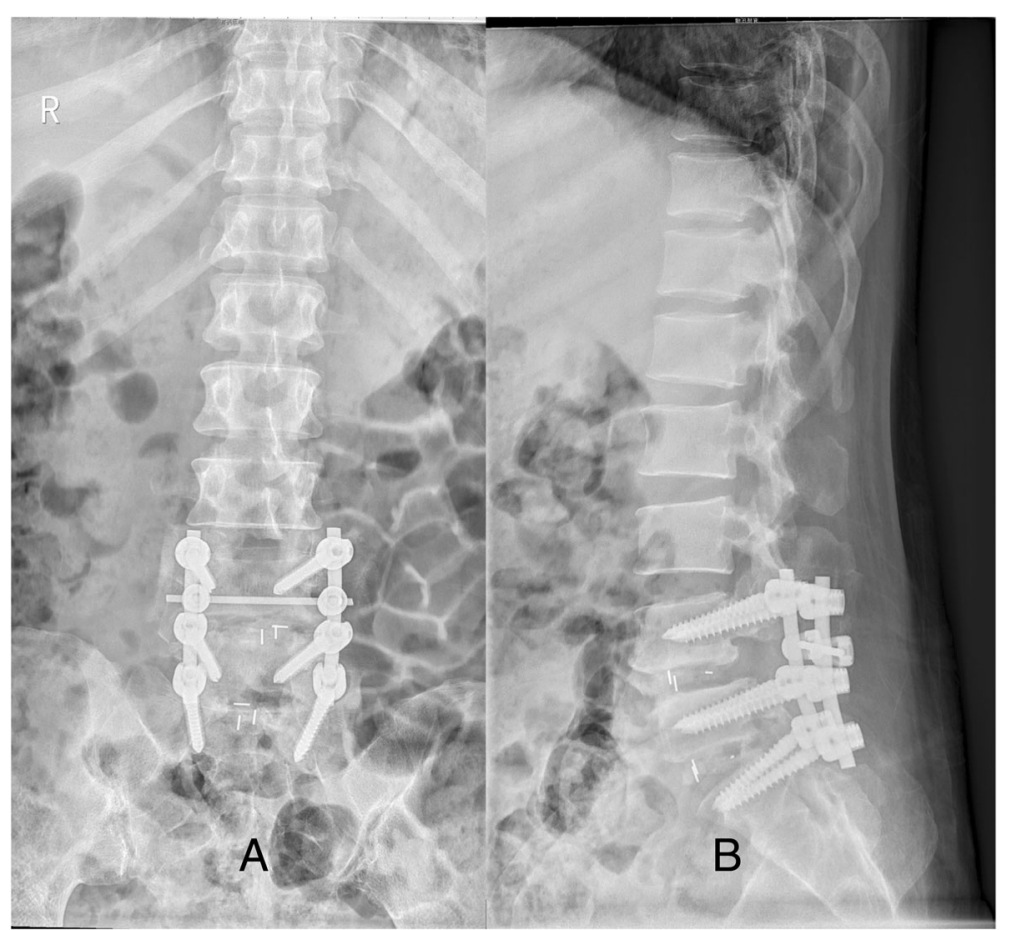

Fig. 3 Postoperative lumbar X-ray after debridement ( $\mathbf{a}$ and $\mathbf{b}$ ) showed gas pseudocyst disappeared with no signs of infection

Table 1 Features of intraspinal gas pseudocyst in previous reports

\begin{tabular}{|c|c|c|c|c|c|}
\hline Reference & $\begin{array}{l}\text { Age }(y r) / \\
\text { sex }\end{array}$ & Primary operation & Reoccurred symptoms & $\begin{array}{l}\text { Imaging findings (CT or } \\
\text { MRI) }\end{array}$ & Treatment \\
\hline $\begin{array}{l}\text { Raynor and } \\
\text { Saint-Louis } \\
{[24], 1999}\end{array}$ & $35 / M$ & L4/5 disc excision & $\begin{array}{l}\text { a foot drop and pain in the same } \\
\text { leg } 15 \text { days later }\end{array}$ & $\begin{array}{l}\text { a gas bubble located at } \\
\text { the right } L 5 \text { lateral recess }\end{array}$ & Conservative treatment \\
\hline $\begin{array}{l}\text { Kaymaz et } \\
\text { al. [25]., } \\
2005\end{array}$ & NR & $\begin{array}{l}\llcorner 4 / 5 \text { discectomy and } \\
\text { foraminotomy }\end{array}$ & $\begin{array}{l}\text { weakness in dorsal flexion on the } \\
\text { contra lateral leg }\end{array}$ & $\begin{array}{l}\text { air trapping within the } \\
\text { L3/4 epidural space }\end{array}$ & Conservative treatment \\
\hline $\begin{array}{l}\text { Capelle and } \\
\text { Krauss [26], } \\
2006\end{array}$ & $50 / F$ & $\begin{array}{l}\text { Removal of } L 5 / S 1 \text { free } \\
\text { herniated disc without } \\
\text { discectomy }\end{array}$ & $\begin{array}{l}\text { recurrent pain in same leg } 4 \text { days } \\
\text { later }\end{array}$ & $\begin{array}{l}\text { epidural gas formation at } \\
\text { the operative site }\end{array}$ & $\begin{array}{l}\text { Failure of conservative treatment } \\
\text { for } 7 \text { days, re-operation }\end{array}$ \\
\hline $\begin{array}{l}\text { llica et al. } \\
{[27], 2006}\end{array}$ & $44 / M$ & $\llcorner 4 / 5$ disc excision & $\begin{array}{l}\text { lower back pain and SLR } 45^{\circ}+5 \\
\text { months later }\end{array}$ & $\begin{array}{l}\text { accumulation of gas in } \\
\text { the lumbar epidural space }\end{array}$ & $\begin{array}{l}\text { Failure of conservative therapy for } \\
1 \text { months, re-operated after no } \\
\text { response }\end{array}$ \\
\hline \multirow[t]{3}{*}{$\begin{array}{l}\text { Sasani et al. } \\
{[28], 2007}\end{array}$} & $62 / F$ & $\begin{array}{l}\text { Microdiscectomy } \\
\text { without foraminotomy } \\
\text { or hemilaminectomy }\end{array}$ & recurrent pain 20 days later & $\begin{array}{l}\text { air bubble in the right } \\
\text { anterolateral portion of } \\
\text { the } L 2 / 3 \text { epidural space }\end{array}$ & Conservative treatment \\
\hline & $72 / \mathrm{F}$ & $\begin{array}{l}\text { Microdiscectomy and } \\
\text { stabilization }\end{array}$ & $\begin{array}{l}\text { recurred pain in left leg } 2 \text { weeks } \\
\text { later }\end{array}$ & $\begin{array}{l}\text { gas collection on the } L 4 / 5 \\
\text { left mediolateral }\end{array}$ & $\begin{array}{l}\text { Failure of conservative therapy for } \\
3 \text { days and needle aspiration for } 2 \\
\text { days; surgery successful }\end{array}$ \\
\hline & $69 / M$ & $\begin{array}{l}\mathrm{L} 5 / \mathrm{S} 1 \\
\text { microdiscectomy and } \\
\text { foraminotomy }\end{array}$ & $\begin{array}{l}\text { radiculopathy in his right leg } 7 \text { days } \\
\text { later }\end{array}$ & $\begin{array}{l}\text { gas bubble in the } L 5 / S 1 \\
\text { epidural space and disc } \\
\text { space }\end{array}$ & Conservative treatment \\
\hline $\begin{array}{l}\text { Chul-Woo, } \\
\text { et al. [29], } \\
2014\end{array}$ & $68 / F$ & $\begin{array}{l}\mathrm{L} 2 / 3 \text { and } \mathrm{L} 5 / \\
\mathrm{S} 1^{\prime} \text { laminectomy and } \\
\text { discectomy }\end{array}$ & $\begin{array}{l}\text { lower back pain and radiating pain } \\
\text { to her left leg similar to } \\
\text { preoperative symptoms } 2 \text { weeks } \\
\text { later }\end{array}$ & $\begin{array}{l}\text { air accumulation } \\
\text { compressing } L 3 / 4 \text { and } L 5 / \\
\text { S1 dural sac and nerve } \\
\text { root }\end{array}$ & $\begin{array}{l}\text { Failure of conservative treatment } \\
\text { for } 2 \text { weeks and needle aspiration } \\
\text { for } 2 \text { days; surgery successful }\end{array}$ \\
\hline
\end{tabular}


may cause spinal cord or root compression and lead to severe neurological symptoms, which may need surgical treatment.

As one possible cause of intraspinal gas, intraspinal gas following spinal surgery is common. Most of postoperative intraspinal gas is asymptomatic and re-absorbed in a few weeks. Only a few cases of symptomatic intraspinal gas have been reported in previous reports (Table 1) [24-29].

The exact origin and pathogenetic mechanisms of postoperative intraspinal gas is still unknown. A few hypotheses were introduced to explain the origin and possible pathogenic mechanisms of gas accumulation in the spinal canal [28]. Some authors believed that postoperative intraspinal gas might be originated from trapped gas within the soft tissue during the operation, intradiscal gas, or spinal structure itself $[28,29]$. There may be the existence of communication between interspinal gas and intradiscal gas. Gas may migrate from operated and adjacent disc to the epidural space through this communication under the normal movements of lumbar spine, just acting as a piston. Finally, intraspinal gas accumulated and increased, leading to dura sac or nerve root compression [13]. What's more, the usage of spinal instrument may provide gap for air accumulation between spinal bone structure and muscle, especially the presence of cross connection.

Different methods have been introduced to treat postoperative intraspinal gas. For asymptomatic intraspinal gas, conservative treatment may be a good choice. Absolute bed rest and immobilization with brace to restrict postoperative lumbar spine motion are recommended to lower the chances of air re-accumulation. Percutaneous needle aspiration had been used to treat asymptomatic intraspinal gas [30]. However, the outcomes of this method are controversial. Some authors reported that intraspinal air re-accumulated and previous symptom re-occurred after percutaneous needle aspiration because of piston-like mechanism and presence of membrane encasing air [29]. Open surgery is recommended in case of no response to conservative treatment or failure of percutaneous needle aspiration. Cyst walls, the gaseous cyst, and the membranous soft tissue near the nerve root during the operation must be removed in order to prevent re-accumulation or persistence of air in the lumbar epidural space. Due to the great advances in endoscopic techniques and equipment, percutaneous endoscopic treatment for the symptomatic epidural gascontaining pseudocyst is also a good choice with sufficient decompression, low recurrence rate, and minimal invasion [31]. Besides, irrigating the surgical field with isotonic saline and longer stay of the drain postoperatively may be helpful to prevent the formation and increase of intraspinal air.

\section{Conclusion}

It is rare that intraspinal gas following spinal surgery causes spinal cord compression. Intraspinal gas may accumulate and become asymptomatic under normal movement of lumbar spine segments. More attention should be paid to this kind of intraspinal gas pseudocyst in case of neurologic symptoms. Proper methods should be chosen to treat this kind of intraspinal gas pseudocyst.

\section{Abbreviations}

CT: Computed tomography; MRI: Magnetic Resonance Imaging

\section{Acknowledgments}

We would like to thank X. M. (Xuexiao Ma), Y. L. (Yong Liu), G. L. (Guanghui Li), and S. L. (Shuzhong Li) for their contribution to the revision of the draft, and to thank D. W. (Dexun Wang) and Z. W. (Zhongying Wang) for their contribution to data collection and data handling in the study.

\section{Authors' contributions}

JG: collected the patient data and drafted the manuscript. DW and ZW: helped collect the clinical and radiographic data of the patient. XM, YL, GL: helped revise the draft. SL: performed the surgery and revised the manuscript critically. All authors read and approved the final manuscript.

\section{Funding}

No funding was obtained for this study.

Availability of data and materials

All the raw data is contained within the manuscript and additional files.

Ethics approval and consent to participate

Not applicable.

\section{Consent for publication}

Written informed consent was obtained from the patient for publication of this case report and any accompanying images.

\section{Competing interests}

The authors declare that they have no competing interests.

Received: 23 October 2018 Accepted: 14 June 2019

Published online: 21 June 2019

\section{References}

1. Anda S, Stovring J, Ro M. CT of extraforaminal disc herniation with associated vacuum phenomenon. Neuroradiology. 1988;30:76-7.

2. Berns DH, Ross JS, Kormos D, Modic MT. The spinal vacuum phenomenon: evaluation by gradient echo MR imaging. J Comput Assist Tomogr. 1991;15: 233-6.

3. Gulati AN, Weinstein ZR. Gas in the spinal canal in association with the lumbosacral vacuum phenomenon: CT findings. Neuroradiology. 1980;20: $191-2$.

4. Hidalgo-Ovejero AM, Martinez-Grande M, Garcia-Mata S. Disc herniation with gas. Spine (Phila Pa 1976). 1994;19:2210-2.

5. Bhalla S, Reinus WR. The linear intravertebral vacuum: a sign of benign vertebral collapse. AJR Am J Roentgenol. 1998;170:1563-9.

6. Becker M, Zbaren P, Hermans R, Becker CD, Marchal F, Kurt AM, Marre S, Rufenacht DA, Terrier F. Necrotizing fasciitis of the head and neck: role of CT in diagnosis and management. Radiology. 1997;202:471-6.

7. Van Lom KJ, Kellerhouse LE, Pathria MN, Moreland SI, Brown JJ, Zlatkin M, Sartoris DJ, Chevrot A, Resnik CS, Resnick D. Infection versus tumor in the spine: criteria for distinction with CT. Radiology. 1988;166:851-5.

8. Charles RW, Mody GM, Govender S. Pyogenic infection of the lumbar vertebral spine due to gas-forming organisms. A case report. Spine (Phila Pa 1976). 1989;14:541-3.

9. Abraham DJ, Vaccaro AR, Albert TJ, Cotler JM. Gas in the spinal canal associated with injury of the cervical spinal cord: a diagnostic dilemma. A case report. J Bone Joint Surg Am. 1997;79:591-3. 
10. Ford LT, Gilula LA, Murphy WA, Gado M. Analysis of gas in vacuum lumbar disc. AJR Am J Roentgenol. 1977;128:1056-7.

11. Yucesoy K, Cakmakci H, Naderi S, Kovanlikaya A. Spinal epidural gas after cardiac surgery. J Spinal Disord. 2001;14:76-8.

12. Grenier N, Grossman RI, Schiebler ML, Yeager BA, Goldberg HI, Kressel HY. Degenerative lumbar disk disease: pitfalls and usefulness of MR imaging in detection of vacuum phenomenon. Radiology. 1987;164:861-5.

13. Yoshida H, Shinomiya K, Nakai O, Kurosa Y, Yamaura I. Lumbar nerve root compression caused by lumbar intraspinal gas. Report of three cases. Spine (Phila Pa 1976). 1997;22:348-51.

14. Larde D, Mathieu D, Frija J, Gaston A, Vasile N. Spinal vacuum phenomenon: CT diagnosis and significance. J Comput Assist Tomogr. 1982;6:671-6.

15. Khodadadyan C, Hoffmann R, Neumann K, Sudkamp NP. Unrecognized pneumothorax as a cause of intraspinal air. Spine (Phila Pa 1976). 1995;20:838-40.

16. Scialdone CJ, Wagle W. Intraspinal air: an unusual manifestation of blunt chest trauma. Clin Imaging. 1990;14:59-60.

17. Knutsson $F$. The vacuum phenomenon in the intervertebral discs. Acta Radiol. 2010;23:648-54

18. Anda S, Stovring J, Ro M. CT of extraforaminal disc herniation with associated vacuum phenomenon: Case reports. Neuroradiology. 1988;30(1): 76-77.

19. Hidalgo-Ovejero AM, Garcia-Mata S, Izco-Cabezon T, Garralda-Galarza G, Martinez-Grande M. Intradural disc herniation associated with epidural gas. Spine (Phila Pa 1976). 1998;23:281-3.

20. Brown WM 3rd, Symbas PN. Pneumocephalus complicating routine thoracotomy: symptoms, diagnosis and management. Ann Thorac Surg. 1995;59:234-6.

21. Assietti R, Kibble MB, Bakay RA. latrogenic cerebrospinal fluid fistula to the pleural cavity: case report and literature review. Neurosurgery. 1993;33:1104-8.

22. Kumar R, West CG, Gillespie JE. Gas in a spinal extradural cyst. Case report. J Neurosurg. 1989;70:486-8.

23. Salpietro FM, Alafaci C, Collufio D, Passalacqua M, Puglisi E, Tripodo E, Di Pietro G, Tomasello F. Radicular compression by lumbar intraspinal epidural gas pseudocyst in association with lateral disc herniation. Role of the posterior longitudinal ligament. J Neurosurg Sci. 2002;46:93-5 discussion 95.

24. Raynor RB, Saint-Louis L. Postoperative gas bubble foot drop. A case report. Spine (Phila Pa 1976). 1999;24:299-301.

25. Kaymaz M, Oztanir N, Emmez H, Ozkose Z, Pasaoglu A. Epidural air entrapment after spinal surgery. Clin Neurol Neurosurg. 2005;107:421-4.

26. Capelle HH, Krauss JK. Recurrent sciatica due to periligamentous trapped epidural gas after spinal sequestrectomy. J Neurosurg Spine. 2006;4:75-7.

27. Ilica AT, Kocaoglu M, Bulakbasi N, Kahraman S. Symptomatic epidural gas after open diskectomy: CT and MR imaging findings. AJNR Am J Neuroradiol. 2006;27:998-9.

28. Sasani M, Ozer AF, Oktenoglu T, Cosar M, Karaarslan E, Sarioglu AC. Recurrent radiculopathy caused by epidural gas after spinal surgery: report of four cases and literature review. Spine (Phila Pa 1976). 2007;32:E320-5.

29. Lee CW, Yoon KJ, Ha SS, Kang JK. Radicular compression by intraspinal epidural gas bubble occurred in distant two levels after lumbar microdiscectomy. J Korean Neurosurg Soc. 2014;56:521-6.

30. Kang SS, Kim MS, Ko KM, Park JC, Hong SJ, Yoon YJ, Shin KM. Symptomatic epidural gas cyst treated with epidural block and percutaneous needle aspiration -a case report. Korean J Anesthesiol. 2012;62:379-81.

31. Zhu B, Jiang L, Liu XG. Transforaminal endoscopic decompression for a Giant epidural gas-containing pseudocyst: a case report and literature review. Pain Physician. 2017;20:E445-e449.

\section{Publisher's Note}

Springer Nature remains neutral with regard to jurisdictional claims in published maps and institutional affiliations.

Ready to submit your research? Choose BMC and benefit from:

- fast, convenient online submission

- thorough peer review by experienced researchers in your field

- rapid publication on acceptance

- support for research data, including large and complex data types

- gold Open Access which fosters wider collaboration and increased citations

- maximum visibility for your research: over $100 \mathrm{M}$ website views per year

At BMC, research is always in progress.

Learn more biomedcentral.com/submissions 